\title{
College English Effective Teaching Approach: Visual Support the Concept Map
}

\author{
Taohua Xiao \\ Jiang xi Institute of Fashion Technology \\ Nanchang, Jiang xi, China 330201
}

\author{
Lina $\mathrm{Wu}$ \\ Jiang xi Institute of Fashion Technology \\ Nanchang Jiangxi, China 330201
}

\begin{abstract}
Visualization support is a conceptual framework. Based on the graphic way, it can intuitively and structurally present the relationship of different knowledge. At present, the visual teaching tools have been widely used in various fields. It also played an important role in English teaching. Hoping to apply this knowledge visualization teaching tools into daily English teaching can let us produce unexpected results.
\end{abstract}

Keywords-college English; effective teaching; visual support; knowledge transfer; concept map

\section{THE EFFECTIVE TEACHING CONNOTAT ION}

Effective teaching is an ideal pursuit of the quality classroom teaching. It is also the core idea of the current teaching reform. [1] It points that a certain teaching inputs (time, experience and effort) brings the best teaching effect. [2] The activities of the effective teaching can reap benefits. It is the transformation of teaching activities, also an activity that pay attention to students' success. Its ideas come from the western scientific education movement in the 20th century, especially in the American philosophy of pragmatism and the influence of behaviorism psychology teaching effectiveness movement. Effective teaching draws attention of scholars from all over the world. The abroad scholars began to focus on effective teaching in the 1960's, while our country scholars began to research effective teaching in the 1990's.

The elements of effective teaching mainly include the following aspects.

- To solve the problem of a class. The problem is likely to be a teacher, the students, or both, but the process of solving is a mutual cooperation between the teacher and the students. Students are the main part of the problem solving and a teacher should offer certain guidance and supervision in the process of problem solving.

- The teacher must have a higher level of academic accomplishment and scientific research. In college, a good teacher should have high level of academic disciplines and academic accomplishment. He can bring their own research and teaching together. It can not only enrich the connotation of the teaching but also expand the depth of the teaching, encourage the occurrence and development of creative thinking, improve the effectiveness of teaching. At the same time, effective teaching can make its research more vitality. ${ }^{[3]}$

- The students must have independent thinking ability, cooperation and exploring spirit.

- Teachers and students participate the activities together in their class. During the teaching teachers should break the traditional authority and take the students as the theme and the teacher as the supervision and guidance role.

\section{THE COLLEGE ENGLISH TEACHING CURRENT SIT UATION}

In 2003 the education ministry launched a teaching reform in college English, the education ministry and higher education department issued "College English curriculum require ments" (trial edition) in 2004 (revised in 2007 formal promulgated). According to this document, all teaching institutions and units the college English curriculum requirements and combined with the status quo of their own schools and students constantly reformed. If we input "college English teaching reform" in China's net, we can get 20170 papers from 2004 to 2015 . By the numbers, we can learn that from 2004 to now how many English teachers and scientific research units were doing research in this field so we know the reformation also achieved a certain result, but, according to the requirement of the new basic outline, the new teaching pattern should take the modern information technology, especially the network technology as the support that can make the teaching and learning of English to a certain extent. New English teaching mode should reflect the principle of combining practical, intellectual and interesting teaching to arouse the enthusiasm of teachers and students. It can reflect the subject status of students and teachers in a leading role in the process of teaching. According to our current teaching situation, there is a certain distance away from the requirement. For example:

- because of the money problem, many universities do have established enough multimedia classrooms at present, is still difficult to meet the needs of students;

- every week many teachers have more than 20 lessons, then it is difficult to find time to study and do research; 
- most colleges and universities young teachers salary is limited, teacher's work enthusiasm are subject to certain restrictions;

- because during the university, college English is a public elective or required courses, most of the students think this course is not important.

\section{VISUAL TEACHING AND COLLEGE ENGLISH TEACHING EFFECTIVELY}

Constructivism believes that learning is a process of an opinion construction. Teachers should let the students fully use the time during class and guide them. In college English teaching, most teachers constrained the class. If we want to make our class more efficient and promote meaningful learning, we must establish a connection between knowledge. Framework (visual teaching mode) can link original English knowledge and new knowledge together. According to it the students can find the meaning behind the knowledge. At last, it can achieve effective teaching.

\section{A. As the Concept of Visual Thinking}

Concept maps not only are a means of cognition to promote students' awareness of learning, they can be used to cultivate and support the learners' cognitive model of visual support tool of thinking. That is through the concept map graphic organization or frame work to present key concepts, or use the concept map to reveal the inner link between knowledge or distinction, the learners based on schema to constantly think and solve problems.

With the deepening of the learners to think of a problem, learners can use visualization organization, concept map to solve complex problems. All kinds of thinking structure designed to be structured, half structured or open frame, which can facilitate users added on the basis of the construction and development. ${ }^{[4]}$

\section{B. Concept Maps Used in College English Teaching Steps}

When the students use concept mapping in college English learning, they can take some steps, such as:

- A concept map has many types of graphic organization, different knowledge to choose different concept map to get the effect will be different. The teacher should first give students an explanation of the different graphic organization types along with their uses.

- Use a knowledge concept map to show knowledge, and students will soon know the advantage of it.

- Concept mapping is applied to the English class.

- Giving students the concept of a blank map will allow students to fill in the form of the concept map. The students meet questions that the teacher will help guide them through.

- Let students create their own concept maps so they will feel a sense of accomplishment.

- The team will create maps and show it to the class, teachers also give comments immediately.
- Accord to the suggestion or opinion the team me mbers constantly correct.

\section{The Application of Concept Map in College English Teaching}

1) Using the concept map can help the teacher to design the teaching effectively. Concept maps can effectively help the teacher to integrate the teaching content and can link old knowledge and new knowledge effectively. So the teacher can use the concept map to effectively show the thinking to the whole class. Thus, it can improve the entire class organizational and logical ability.

2) Using concept maps in English class is good for the students' cooperative learning. Before formal classroom learning, teachers divide students into several groups, each group member is 5-6 people, everyone can use their hand draw the content what teacher speak or they expressed own ideas and opinions in the form of concept map, then discuss it together. This way can improve students' problem solving ability and cooperation spirit.

3) Using the concept map can help their individual learning. In college English reading, students can use the concept map to process the article. Establishing the network structure of knowledge can connect the old and new knowledge, finding the inner link between knowledge. So it can grasp the main points of the knowledge on the whole and enrich the knowledge of deconstruction. The concept map provides a good bridge for the students' learning. Through this framework, one can arouse the students' initiative in English learning and, which will improve the students' self learning ability.

4) The concept map can be used as the evaluation of English teaching tool. Using concept maps as an assessment tool is suitable for all stages of the whole process of teaching. It can be used as a formative assessment tools. Teachers can know the whole process by observing the students making concept maps and can also can know the situation to understand the students' inner thinking activity. When facing problems, the teachers can give them guidance and evaluation immediately.

\section{REFERENCES}

[1] CAI baolai, CheWei colourful. Effective classroom teaching: the connotation, features and constituent elements [J]. Journal of education scientific research, 2013 (1)

[2] li-min yao. The study of the characteristics of effective teaching [J]. Journal of modern university education, 2001 (4)

[3] Wei Shanchun. Effective teaching: objectives, factors and implementation may - a review process philosophy [J]. Journal of teaching of modern university, 2013 (1)

[4] Xiong Pin, xiao-yong hu bracket of visual thinking, concept map a new perspective of research [J]. Journal of information technology education, $2005(10)$ 